\title{
Slow But Sure: Discourse Analysis on Sharia Regional Regulation and Its Derivatives
}

\author{
Agustina ${ }^{1}$ Muhammad Adek ${ }^{1, *}$ \\ ${ }^{1}$ Indonesian Department, FBS Universitas Negeri Padang, Padang, Sumatra Barat, 25131, Indonesia \\ "Corresponding author. Email: marximalize@fbs.unp.ac.id
}

\begin{abstract}
It is undeniable that the emergence of regulation with Islamic overtone in Indonesia often creates polemics in the midst of society, especially from the point of view of democracy and human rights. This study aimed to explicate the expansion of the discourse on the Sharia Regional Regulations in West Sumatra as one of the pioneers of the enactment of Sharia rules in the Regional Autonomy era. This is conducted through tracking related texts of the discourse on Sharia bylaws that have been published previously and are implemented by the local bureaucracy. The critical discourse approach and the BREAK theory are combined in an effort to disentangle the inter-text linkages in the Sharia rules discourse, regarding of the form, message and the motive behind it. The primary research findings state that there a tendency to expand the discourse on Sharia Regional Regulations which are modified into more persuasive forms such as work programs and regional policies by local governments. However, there is also a stronger impression of antagonism to enforce the total implementation of Sharia by interested parties. Both of these discoveries reflect a tug of war between interested parties which has an impact on the decline in the quality of democracy and violations of citizens' rights.
\end{abstract}

\section{Keywords: Indonesian democracy, Sharia regional regulation, West Sumatra, critical discourse analysis}

\section{INTRODUCTION}

Currently, almost all democratic countries around the world are regressing, including Indonesia. Some experts argue that Indonesia has actually experienced a significant decline in recent years [1-4]. This situation is quite ironic considering the Freedom House report in 2007 [5] categorizes Indonesia as the only "free democracy" in Southeast Asia. So far, majority of researchers claim that the threat to Indonesian democracy comes from political contestation at the national level such as identity politics in elections [6]. However, few have turned their eyes to an equally serious threat, namely local level friction.

The barrier to national democracy referred to above is the application of the Sharia Regional Regulation. Although using Sharia diction, this regulation contains more of a set of prerequisite rules based on Islamic teaching sources that focus on aspects of morality and social ills [7], [8], [9], [10]. Some of the regions that have issued regulations of this kind the most intensively are West Java, South Sulawesi and West Sumatra. In this paper, the discussion will focus only on the province of West Sumatra.

The implementation of the Sharia Regional Regulation in West Sumatra is a manifestation of the local wisdom in the era of regional autonomy. Regional leaders have full authority in implementing this rule without being dictated again by the central government [11]. In practice, this regulation is often juxtaposed with an appeal or circular in an effort to prevent and eradicate immorality (societal disease) and save the nation's morals [12]. Not surprisingly, the presence of this Sharia Regional Regulation is seen as a gateway for other regulations or programs that carry the same spirit.

Several scholars claim several reasons related to the proliferation of sharia regional regulations in Indonesia. The first claim states that the issuance of the Sharia Regional Regulation is a camouflage for corruption/incompetence in running the government. This phenomenon was identified by Bush [9] who conducted case studies in Bulukumba and Aceh. There is another conclusion which expresses that this regulation is a political commodity/mass mobilization. This message was detected from a background analysis towards the regional head who published it and the publication period which was very strong in political nuance. Other findings suggest that productive regions issued these regulations is an area that has historically desired to establish a state based on Islamic law, such as West Java and South Sulawesi. These two areas are the locus of the occurrence of an Islamic state in Indonesia in the past. Various kinds of motives will also be explored in the discourse study of the regional sharia regulations in West Sumatra.

Regarding the quality of democracy and human rights, Sharia regional regulations are prone to causing genderbased discrimination. Several studies suggest that women are the most vulnerable group in implementing these 
regulations [13], [14], [15]. Some regulations are specifically aimed at women, such as clothing, the ability to recite the Koran, the application of curfews and so on. Not surprisingly, Sharia regional regulations are seen as a serious challenge in democratic state recently.

Current research findings neither describes nor explains the develompent of Shariah bylaws sufficiently. A large portion of the current studies center around the results of embracing Sharia regulation including human rights, treatment of women and religious minorities, and broader state-religion relations. In recent years, a more focused literature has emerged researching sharia regional regulations in West Sumatra however, it focuses on conflicts of inheritance [16] and minorities [17]. This paper intends to discuss the progress of the Sharia Regional Regulation in West Sumatra related to the decline in the quality of democracy because it still has some lack of literature. In addition, the analysis of the development of the regional religious regulation also aims to reveal the causes and effects of the emergence of these regulations.

\section{METHODS}

Basically, this research applied two approaches. The first is a theoretical approach as a frame of mind. The theory of BREAK [18]. was chosen as the viewpoint because it views discourse as the process of identifying the object of investigation namely social phenomena and their complexity rather than merely a linguistic unit [19]. Furthermore, this study focuses on Textual Relations. This feature includes an inter-text analysis related to the Perda Syariah in West Sumatra. This analysis aims to discuss the discourse that is closely related to the discourse of sharia regional regulations in West Sumatra. The relation between these texts are identified through comparison of configurations which composes the body of text.

Furthermore, there is a critical discourse approach (CDA) as a research design. This approach can act as a set of tools or methods for examining the basic units of analysis, for example, text, discourse, conversation and speech acts. In addition, this approach positions discourse as a form of social practice, one of which looks at the power relationship between the ruler and the ruled [20]. In this study, the power relation reflected is between the provincial government of West Sumatra and its apparatus as policy makers and the community as the object regulated in the policy.

The data source chosen was the news document in the mass media. Mass media was chosen because of its strategic position in a democratic country, namely the mass media as a watchdog [21]. which has the potential to capture objectively the relationship between ruler parties and ruled groups in a news discourse. Through this paradigm,it is hoped that the data displayed by the mass media can provide insight into variable of relationship between the implementation of Sharia regional regulation and its derivatives.

The document review method was implemented in the data collection process. Mass media documents are read closely and separated based on the research theme, namely related to the regional regulation on sharia in West Sumatra. Once collected, the data are grouped according to the type of discourse on Sharia regulations.

The data analysis work process is implemented in two steps. The first analysis is to dissect the language aspects. This step was completed by using the distributional method followed by the Ultimate Constituent Analysis. Both processes aim to get an understanding of the meaning to be conveyed from the analyzed language data. This micro-analysis is very important in understanding meaning behind the text however it is regularly overlooked by researchers who use critical discourse approaches [22].

The second step used is the participatory method. This method combines several types of analysis such as comprehensive, contextual, and multilevel. This method is implemented by placing the researcher as a participant in the social transformation process. Participants here mean that the researcher is an inseparable part of the discourse that is being analyzed. In addition, researchers' understanding of violations of democratic values is also used in interpreting the data. In short, researchers position themselves as speech partners who interpret discourse related to Sharia regional regulations in newspaper reporting. By combining the two steps above, it is hoped that a complex understanding of the discourse on sharia regional regulations and their derivatives in West Sumatra can be achieved.

\section{FINDINGS}

Based on the analysis of the data that has been collected, the following results are obtained: 
Table 1. Texts related to the discourse on sharia regional regulations in West Sumatra

\begin{tabular}{|c|c|c|c|}
\hline No. & Variable & $\begin{array}{c}\text { The Pattern of Sharia Regional } \\
\text { Regulation Discourse }\end{array}$ & Related Texts \\
\hline \multirow[t]{3}{*}{1.} & \multirow[t]{3}{*}{$\begin{array}{l}\text { "Pandai Baca Tulis } \\
\text { Alquran"/ Able to read } \\
\text { and write the Koran } \\
\text { (hereinafter PBTA } \\
\text { Discourse) }\end{array}$} & \multirow[t]{3}{*}{$\begin{array}{l}\text { Subject + must be able+ to } \\
\text { read and write the Koran }\end{array}$} & $\begin{array}{l}\text { (1a) Pemkot Padang Wajibkan ASN Subuh } \\
\text { Berjamaah Sekali Sebulan } \\
\text { Padang City Government require the staff to } \\
\text { attend fajr congregation once a month }\end{array}$ \\
\hline & & & $\begin{array}{l}\text { (1b) SDN } 18 \text { Koto Panjang Terapkan Program } \\
\text { Puasa Senin-Kamis dan Tahfidz Qur'an Kepada } \\
\text { Siswa/Siswi. } \\
\text { SDN } 18 \text { Koto Panjang implement Monday- } \\
\text { Thursday Fasting and Tahfidz Qur'an program } \\
\text { for students. }\end{array}$ \\
\hline & & & $\begin{array}{l}\text { (1c) Gerakan Masyarakat Maghrib Mengaji, } \\
\text { Dicanangkan. } \\
\text { Post-magrib recital movement was planned. }\end{array}$ \\
\hline \multirow[t]{8}{*}{2.} & \multirow{8}{*}{$\begin{array}{l}\text { "Berpakaian Muslim dan } \\
\text { Muslimah"/Wearing } \\
\text { Muslim and Muslimah } \\
\text { Dress (hereinafter BMM } \\
\text { Discourse) }\end{array}$} & \multirow[t]{8}{*}{$\begin{array}{l}\text { Subject }+ \text { must }+ \text { wear Islamic } \\
\text { dress code }\end{array}$} & $\begin{array}{l}\text { (2a) Wanita Tak Berhijab Ditegur Masuk Masjid } \\
\text { Raya Sumbar } \\
\text { Women without veil were reprimanded for } \\
\text { entering the Great Mosque of West Sumatra }\end{array}$ \\
\hline & & & $\begin{array}{l}\text { (2b) MUI Sumatera Barat Tolak Islam Nusantara } \\
\text { West Sumatra MUI Rejects Islam Nusantara }\end{array}$ \\
\hline & & & $\begin{array}{l}\text { (2c) MUI Sumbar Tolak SE Kemenag Terkait } \\
\text { Pengeras Suara } \\
\text { West Sumatra MUI Rejects Ministry of } \\
\text { Religion's notification letter regarding } \\
\text { loudspeakers }\end{array}$ \\
\hline & & & $\begin{array}{l}\text { (2d) MUI Sumbar: Haram Rayakan Hari } \\
\text { Valentine } \\
\text { West Sumatra MUI: it is forbidden to celebrate } \\
\text { Valentine's Day }\end{array}$ \\
\hline & & & $\begin{array}{l}\text { (2e) Ketua MUI Sumbar Haramkan Muslim Pilih } \\
\text { Partai yang Tolak Perda Syariah } \\
\text { West Sumatra MUI chairman forbade Muslims } \\
\text { from choosing parties that reject the Sharia law }\end{array}$ \\
\hline & & & $\begin{array}{l}\text { (2f) MUI Sumbar Haramkan Neraka dan Setan } \\
\text { untuk Nama Produk } \\
\text { West Sumatra MUI prohibits (to use) Hell and } \\
\text { Satan for product names }\end{array}$ \\
\hline & & & $\begin{array}{l}\text { (2g) DPRD Kota Padang Dorong Pasal } \\
\text { Pengawasan Jam Malam bagi Remaja } \\
\text { DPRD Padang City Pushes Article for } \\
\text { Supervision of Curfew for Adolescents }\end{array}$ \\
\hline & & & $\begin{array}{l}\text { (2h) LKAAM Sumbar Imbau Pedagang Ubah } \\
\text { Nama Ekstrem Menu Makanan } \\
\text { LKAAM West Sumatra urges traders to change } \\
\text { the extreme name of the food menu }\end{array}$ \\
\hline
\end{tabular}

The analysis of textual relations in BREAK's theory aims to trace the appearance of texts related to the discourse being discussed (main discourse). By using an intertextual frame of mind, this investigation is expected to capture diverse texts in terms of form, essence or spirit. Through this work process, the deepening of analysis and understanding of the main discourse can be carried out comprehensively. The analysis section below describe the texts related to the text in the main discourse through analysis related to the three features of the Discourse Basis elements, namely the elements of form, essence and spirit. 


\subsection{The PBTA Discourse}

\subsubsection{Form Analysis}

The form of text that appears in the PBTA discourse is dominated by a uniform structure, namely imperative sentence. Besides that, this discourse also uses the imperative mode which is relatively similar, namely 'obligatory'. The objects that are regulated in this discourse (students, future brides, workers and educators) are always positioned at the beginning of the sentence and closed with the problems imposed (read and write the Koran) on the subject at the end of the structure. This uniform pattern appears repeatedly in the discourse text of PBTA although issued by different sources.

The texts that are related to the PBTA discourse have a relatively similar form. In related texts (1a) and (1b), the form of the imperative sentence still appears as the main pattern. This is identified through verbs that fill the predicate functions, namely 'oblige' and 'apply'. The two verbs have quite different levels of emphasis where the word 'oblige' has a stronger emphasis than the word 'apply'. In contrast to the main discourse PBTA, the text forms (1a) and (1b) do not place arranged Objects such as 'ASN' and 'students' at the beginning of the structure. In contrast to the main discourse, the identity of the subject (actor) in the two related texts is clear and prominent.

Significant differences in form are found in the form of related text (1c). This text is not an imperative type like the previous texts. This text is included in the commissive sentence which is identified by the predicate 'dicanangkan'/planned where the subject (unidentified) is committed to the formation of a program called 'magrib mengaji' (post-magrib recital) in the future. Similar to the main discourse, the subject (actor) is not presented in the text but the regulated object ('masyarakat'/public) and the imposed rules ('magrib mengaji'/post-magrib recital) remain.

Although related texts have different forms, the three texts have a very close relationship. The relationship between the three texts and the main discourse is implementation of regulations/policies by local governments related to the imposition of religious matter for the community. This is indirectly related to violations of democratic values, namely the imposition of religious practices. According to BPS calculations, the discourse on PBTA is classified as violations of Civil Liberties, the Freedom of Belief variable and indicator number 5 .

\subsubsection{Essence Analysis}

BREAK theory believes that the form of text is a gateway in understanding the ideas/thought/messages contained in a discourse. This is possible because the form of the text is the main source of guidance in understanding the ideas/ messages contained in the text. The ideas that can be put forward from the related texts above are the active role of the government and its apparatus in formulating sharia regulations.

This idea can be identified from the form of related texts (1a) and (1b). As has been revealed in the form analysis section, the subject-actors ('Pemkot Padang'/Padang City
Government and 'SDN 18 Koto Panjang') in these two texts begin to appear and be highlighted in the structure. Whereas, in the main discourse pattern, the subject-actor is hidden from the structure. This means that the Subjectactor is not an important element to highlight its presence. In related texts, Subject-Doer prominence is manifested through a fronting strategy. With this mechanism, the subject-actor will be exposed clearly and can be clearly identified by readers.

The idea of the active role of the government and its apparatus in producing sharia regulations can also be found in the form of related texts (1c). However, this message is not obtained from the positioning strategy of the subject (actor). This idea is shown through the verb filling in the predicate 'planned', which means there is an action in the future.By saying future planning to the public, the local government has indirectly shown its active role and commitment in crrating programs that have religious connotations.

\subsubsection{Spirit Analysis}

Spirit analysis seeks to reveal the motive, purpose or orientation of a discourse. The spirit identified from the text related to the discourse of PBTA is a show of Islamic political supremacy. This motif is indirectly identified through the form displayed by the texts themselves. In the related text (1a), the subject-perpetrator (Pemkot Padang) issues a regulation that urges and disturbs the privacy area of the object-patient (ASN), namely 'subuh berjamaah'/dawn-prayer congregation. The same pattern appears in related text (1b) which these regulations (Monday-Thursday Fasting and Tahfiz Alquran) are unsuitable and unsubstantial for the object (public school students) imposed. In related text (1c), local government continues to focus on additional programs (Magrib Mengaji) and are not related to the main concerns in that territory. All of these non-substantial programs only aim to strengthen the supremacy of Islamic politics through vivid displays of social piety. The spirit of the related texts above can be understood by its presence in that context Islamic politics is the main commodity in the dynamics of the power-dragging of local governments in West Sumatra. West Sumatra, which is inhabited by the majority of the Minangkabau ethnic group, has always prioritized Islam as a life guide. Especially since the people of West Sumatra adopted ABS-SBK as an adjustment to Custom and Religion, hence the majority of local government programs will be equipped with an Islamic overtone to solve all problems that occur in each region.

\subsection{The BMM Discourse}

\subsubsection{Form Analysis}

Nearly equivalent to the PBTA discourse, the BMM discourse also takes the form of a declarative sentence. This structure contains the object that is arranged, followed by the verb statement and completed by the thing stated.In general, subject-actors i.e. local government does not appear in the BMM Discourse. For texts related to BMM discourse, there are three categories of being 
identified. Each form is separated based on the filler constituents of the Subject or the role of the actor (agentive).

The first form of related texts is a structure without a subject $(\theta \mathrm{S})$. This is identified in related text $(2 \mathrm{a})$ which contains only the Object constituents, verb statements and adverb. The absence of the Subject element or the role of the agent in this form is manifested through an passivation strategy. Thus, the Subject function can be ommitted within the structure.

The next form of related text is a clause with a specific subject, namely 'MUI'. This category appears mostly in texts related to BMM discourse. The structure of this text is not much different from one another. Particularly, the subject (actor) is always in front, followed by the imperative verb and ended by the (patient) Object. Apart from the repetitive Subject-filling pattern, Predicate-filling pattern also occupied by statement verbs which are rejection like the words 'haram' or 'haram'/forbide and 'tolak'/refuse.

The last identified form of related text is a clause with a non-MUI subject. The contents of the Subject function in this pattern are part of the local government, such as 'DPRD Kota Padang' and LKAAM Sumbar'. For the content of the predicate, it consists of a persuasive statement such as the verb "dorong/accelerate" and "ajak/invite".

\subsubsection{Essence Analysis}

Based on the form analysis in the previous sub-analysis, the essence identified from the related texts above is the change in the face of Islam in West Sumatra. The Islamic image in Indonesia which is known to the world so far is a friendly and moderate Islam. However, based on the analysis of the previous form, the intended impression does not appear that way. This phenomenon is most evident in texts relating to the type of MUI subject.

In these categorized texts, we find negation verbs with a high level of emphasis such as 'tolak/reject' $(2 b, 2 c)$ and very high such as 'forbid/haram' (2d) and 'forbid/haramkan' (2e, 2f). The issues being challenged ranged from the issue of faith/aqidah (Islam Nusantara) to non-substantial cases (product naming). This phenomenon is quite interesting considering the subject (perpetrator) who stated that this was an official institution filled by Muslim scholars. This can also imply that this statement represents the opinion of the majority of Muslims in the West Sumatra region.

Another message that can be traced from the related texts above is excessive intervention to the private space of citizens. This is traced to two related texts $(2 \mathrm{~g}, 2 \mathrm{~h})$. Both texts show the existence of efforts to regulate the private space of residents, such as setting the curfew $(2 \mathrm{~g})$ to naming the food menu ( $2 \mathrm{~h})$. Although, these activities are still in the provision $(2 \mathrm{~g})$ and habituation $(2 \mathrm{~h})$ stages, at least the two propositions represent an inappropriate focus made by government agencies in West Sumatra.

The last essence that can be identified from related texts is gender-based sentiment. Based on data (2a), the entity that becomes the victim is a "woman not wearing a hijab". It can be understood that women's religious judgments are based solely on the clothes they wear. This phenomenon shows a superficial and literal understanding of religion from the public so that it is easy to generate sentiments, especially female gender.

\subsubsection{Spirit Analysis}

The spirit reflected in the related texts above is religious exclusivity. This phenomenon can be seen from several of the cases above. The first case is the arrangement for violators of sharia. This can be seen from the efforts to curb those who are deemed to have violated the law, such as women who do not wear the hijab (2a) and teenagers who come out at night $(2 \mathrm{~g})$. The two objects are repressed and separated so as not to set a bad precedent for other societies. This kind of separation is a form of exclusivity in religious practice in West Sumatra.

Another case is the fierce attitude of the MUI which is reflected in the five related texts. Three rejections were addressed to sources originating from the center (Jakarta), namely 'Islam Nusantara'/Archipelago Islam (2b), SE Ministry of Religion (2c) and the Anti-Sharia Regulation (2e). Two other objections to ritual matters are the celebration of Valentine's Day (2d) and the naming of food products (2f). Rejection is characterized by an excessive level of emphasis as reflected in the verbs 'tolak'/reject and 'haram'/forbid. The non-comprimistic attitude of the Muslim intellectual council in West Sumatra represents a strong difference between the implementation of Islam at the local level and outside West Sumatra.

\section{DISCUSSION}

Based on the results of the configuration analysis of texts related to the discourse of Sharia Regional Regulations in West Sumatra, it is found several insights that deepen understanding of the ongoing democratic situation in the Minangkabau area. The first point is the rise of local government programs with the same theme. This can be identified in texts related to the PBTA discourse. The programs in question include "Subuh berjamah"/Fajr congregation (1a), "Puasa Senin-Kamis"/MondayThursday fasting and "Tahfiz Quran" (1b) and "Maghrib Mengaji"/post-Maghrib recital (1c).

Bush [9] believes that the above programs, like Sharia Regional Regulations, are nothing but camouflage and distraction in hiding the corruption that is happening in that municipalities. Bush provided evidence of cases in two different locations that applied similar regional regulations, namely Bulukumba (Sulsel) and Dompu (NTB) districts. Another opinion from Pisani and Buehler [23] indicates that religious programs are issued by the authorities to fulfill requests in an effort to gain public sympathy in facing re-election. In separate research, Buehler [7] found that such programs are adopted by politicians and local elites to mobilize the masses. Another key thing to remember, Buehler also highlighted an interesting phenomenon that regional leaders from secular parties produce more Sharia regional regulations than local elites with Islamic backgrounds. From the studies 
mentioned earlier, this lead to the conclusion that the discourse on Islamic-oriented regulations and their derivatives is a "wild card" that can be exploited by local politicians and rulers in smoothing their respective political goals. In this context, it is worthwhile to consider that the implementation of Sharia regional regulation does not aim to uphold the Islamic spirit but is a vehicle to bring them to the top of power or the status quo.

The second insight from the findings above is the increasing intensity of discriminatory acts against women. The most obvious aspect concerns women's clothing. The Sharia regional regulations on Muslim and Muslimah Dress (BMM) have gradually created binary boundaries towards female genderso as not to accept practices beyond those that have been outlined. This kind of view has indirectly injured the spirit of 'kebhinekaan' (diversity) including in the effort to perform religious teachings which has been guaranteed by the Constitution.

The same logic underlies with the findings of the National Women's Commission (2010) which noted at least 421 Sharia Regional Regulations contain Acts of Discrimination and 333 of them place women as their main targets [13]. This verdict is also supported by the findings of Fanani [12] which also states that women are the most vulnerable group in implementing the Sharia Regional Regulation. Nur Rif'ah [14] adds that the Sharia Regional Regulation is discriminatory against women because policy-making actors are dominated by men who have a gender-biased understanding and have a patriarchal ideology. In another observation, Suryakusuma [24] has also detailed the forms of discrimination against women in the form of restricting freedom of expression (64 rules), dress code (21 rules), to curfew restrictions and prostitution (37 rules). This phenomenon is even more ironic when looking at the history that it was women who contributed greatly to reforming Islamic understanding in West Sumatra until it reached the phase of modernity.

The contradictory attitude shown by the West Sumatra branch of the MUI is also an important point to highlight regarding Identity Politics. Based on texts related to BMM discourse, it is clear that this institution is very active and vocal in supporting local government programs in enforcing Sharia regulations and their derivatives. Other official institutions such as LKAAM and DPRD even just to make appeals only. In other cases, the West Sumatra MUI also firmly stated its rejection of the central government's instructions regarding religious issues. It can be seen here that the West Sumatra MUI has a large portion of authority in determining policies regarding religious issues in the West Sumatra regional government. The phenomenon of significant involvement from the MUI is in line with the findings of Van Bruinessen [25] who also identified the active political movement of the MUI after the fall of the Suharto regime. The MUI, which was originally formed to become an extension of the central government, has turned into an institution that is at a distance from its maker. In addition, according to Ichwan [26] this distancing attitude is motivated by the aim of the MUI to purify Islamic teachings towards orthodoxy. The prediction of involvement from MUI is also in step with the findings of Salim [27] which states that there is support from interested parties who stimulate the issuance of Sharia Regional Regulations in various regions. For those reasons, the meeting point of this verdict with the three related researches is that the West Sumatra MUI makes the discourse on Sharia Regional Regulations and their derivatives as their practical political contestation while demonstrating a conservative Islamic identity at the regional level.

\section{CONCLUSION}

Implementation of local regulations with an Islamic overtone in West Sumatra has had an alarming derivative effect in the light of state democracy especially in the aspect of Religious Freedom. This phenomenon is reflected in the research findings which shows that the discourse on this Sharia Perda has triggered the issuance of other regulations with the same spirit, namely forcing the public to practice their religion. Not only triggering the emergence of other discriminatory regulations, the Sharia Regional Regulation also increases marginalization and repression against gender minorities, especially women. No doubt, the situation and quality of democracy in West Sumatra is getting more and more alarming.

For most scholars and experts in Indonesia, the presence of religious-based regional regulations is claimed to be one of the sources of fertilizing the seeds of intolerance at the provincial level. As the second most productive region to produce Sharia regional regulations in Indonesia, the position of the province of West Sumatra is like a fire in the husk which over time will create a greater potential for conflict. The BPS report on Democracy Index and the Religious Harmony report from the Ministry of Religion recently seemed to justify this situation. With such facts, the West Sumatra Regional Government and the Central Government must find a win-win solution so that these little sparks do not become deadly time bombs in the future.

\section{ACKNOWLEDGEMENT}

This work was funded by a competitive grant distributed by RISTEK/BRIN (DIPA042.06.1.401516/2019) and fully supported by LP2M Universitas Negeri Padang.

\section{REFERENCES}

[1] E. Aspinall and M. Mietzner, "Indonesian politics in 2014: Democracy's close call," Bull. Indones. Econ. Stud., vol. 50, no. 3, pp. 347-369, 2014.

[2] E. Warburton, E. Aspinall, and Post-doctoral research fellow at the Asia Research Institute, National University of Singapore, "Explaining Indonesia's democratic regression: Structure, agency and popular opinion," Contemp. Southeast Asia, vol. 41, no. 2, pp. 255-285, 2018. 
[3] T. P. Power, 'Jokowi's authoritarian turn and Indonesia's democratic decline," Bull. Indones. Econ. Stud., vol. 54, no. 3, pp. 307-338, 2018.

[4] T. Power and E. W. (Eds), Democracy in Indonesia: From Stagnation to Regression? Singapore: ISEAS-Yusof Ishak Institute., 2020.

[5] F. House, "The Worst of the Worst: The World's Most Repressive Societies," 2007.

[6] M. Mietzner, "How Jokowi won and democracy survived," J. Democr., vol. 25, no. 4, pp. 111125, 2014.

[7] M. Buehler, "Subnational islamization through secular parties: Comparing Shari'a politics in two Indonesian provinces," Comp. Polit., vol. 46, no. 1, pp. 63-82, 2013.

[8] M. Buehler, "State elites and the influence of Islamist activists," in The Politics of Shari'a Law, Cambridge: Cambridge University Press, 2016, pp. 9-41.

[9] R. Bush, "10. Regional sharia regulations in Indonesia: Anomaly or symptom?," in Expressing Islam, G. Fealy and S. White, Eds. Singapore: ISEAS-Yusof Ishak Institute Singapore, 2008, pp. 174-191.

[10] T. Lindsey, "7 when words Fail Syariah law in Indonesia: Revival, reform or transplantation?," in Examining Practice, Interrogating Theory: Comparative Legal Studies in Asia, Brill | Nijhoff, 2008, pp. 195-222.

[11] J. G. C. Holtzappel and M. Ramstedt (eds), Decentralization and regional autonomy in Indonesia: Implementation and challenges. Singapore, Singapore: Institute of Southeast Asian Studies, 2010.

[12] A. F. Fanani, "The implementation of sharia bylaws and its negative social outcome for Indonesian women," Indones. J. Islam Muslim Soc., vol. 7, no. 2, p. 153, 2017.

[13] K. Perempuan, “Atas Nama Otonomi Daerah: Pelembagaan Diskriminasi Dalam Tatanan Negara-Bangsa Indonesia,” 2010.

[14] E. N. Rif'ah, "Contesting Islamic Law and Women's Rights: The Study of the Implementation of Sharia-Influenced Regional Regulations (Perda Syariah) in Indonesia," in 7th Asian Law Institute Conference, 2010.

[15] S. M. Mulia, "Perda Syariat dan Peminggiran Perempuan," Tashwirul Afkar, vol. 20, pp. 2144, 2006.

[16] A. Wanto, "Sharia, two sides of the same coin: The contradictions between sharia and adat (case studies of Minangkabau's matrilineal and land tenure system)," Walisongo J. Penelit. Sos. Keagamaan, vol. 25, no. 1, p. 1, 2017.

[17] W. Azwar, "The Resistance of Local Wisdom Towards Radicalism: The Study of the Tarekat Community of West Sumatra Indonesia," Pertanika Journal of Social Sciences \& Humanities, vol. 26, no. 1, pp. 75-102, 2018.

[18] Sawirman, E135 Reader: Media Meliput Teror. Padang: Pusat Studi Ketahanan Nasional dan Universitas Andalas, 2014.

[19] M. Meyer and R. Wodak, Eds., Methods for critical discourse analysis, 2nd ed. London, England: SAGE Publications, 2009.

[20] M. Foucault, Archaeology of knowledge, 2nd ed. London, England: Routledge, 2013.

[21] D. E. Johnson, "The mass media's dual role: 'watchdog' and guardian of their own interests: Mass media's dual role: watchdog and guardian," J. Public Aff., vol. 14, no. 3-4, pp. 369-378, 2014.

[22] Sawirman, "Simbol Lingual Teks Politik Tan Malaka: Elaborasi, Signifikasi, dan Transfigurasi Interteks," Universitas Udayana, Denpasar, 2005.

[23] E. Pisani and M. Buehler, "Why do Indonesian politicians promoteshari'alaws? An analytic framework for Muslim-majority democracies," Third World Q., vol. 38, no. 3, pp. 734-752, 2017.

[24] J. Suryakusuma, "All the President's Men. And the Women?," Jakarta Post, 2010.

[25] M. van Bruinessen, "1. Introduction: Contemporary developments in Indonesian Islam and the 'conservative turn' of the early twentyfirst century," in Contemporary Developments in Indonesian Islam, Singapore: ISEAS-Yusof Ishak Institute Singapore, 2013, pp. 1-20.

[26] M. N. Ichwan, "3. Towards a puritanical moderate Islam: The majelis ulama Indonesia and the politics of religious orthodoxy," in Contemporary Developments in Indonesian Islam, Singapore: ISEAS-Yusof Ishak Institute Singapore, 2013, pp. 60-104.

[27] A. Salim, "Which and Whose Shari'a?: Historical and Political Perspectives on Legal Articulation of Islam in Indonesia," IndoIslamika, vol. 2, no. 1, pp. 31-44, 2012. 